\title{
PENGEMBANGAN LEMBAR KERJA PESERTA DIDIK (LKPD) FLUIDA STATIS DENGAN SCIENTIFIC APPROACH UNTUK MENINGKATKAN KETERAMPILAN BERPIKIR KRITIS SISWA SMAN KOTA BENGKULU
}

\author{
Rensi Purnama Sari, Indra Sakti, Dedy Hamdani \\ Program Studi S1 Pendidikan Fisika Universitas Bengkulu \\ Jalan WR. Supratman, Kandang Limun Bengkulu \\ e-mail: purnamasarirensi@gmail.com
}

\begin{abstract}
ABSTRAK
Penelitian ini bertujuan untuk menghasilkan Lembar Kerja Peserta Didik (LKPD) Fluida Statis dengan Scientific Approach untuk meningkatkan Keterampilan Berpikir Kritis Siswa SMAN Kota Bengkulu. Penelitian ini merupakan jenis penelitian pengembangan (Research and Development) dengan tipe rancangan level 1 yang terdiri dari 5 tahapan, yaitu: 1) potensi dan masalah 2) studi literatur dan pengumpulan informasi 3) desain produk 4) validasi desain 5) desain teruji. Validasi desain dilakukan oleh 2 judgement ahli dan 2 praktisi untuk menilai produk yang dikembangkan dari aspek kelayakan isi, penggunaan bahasa, penyajian dan kegrafisan. Berdasarkan hasil uji validitas aspek kelayakan isi 87,5\% dengan kategori sangat baik, aspek penggunaan bahasa didapatkan hasil persentase sebesar 83,4\% dengan kategori sangat baik, aspek penyajian sebesar 89,1\% dengan kategori sangat baik dan aspek kegrafisan sebesar 93,8\% dengan kategori sangat baik. Berdasarkan hasil tersebut, dapat disimpulkan bahwa LKPD fluida statis dengan scientific approach untuk meningkatkan Keterampilan berpikir kritis siswa SMAN kota Bengkulu yang dikembangkan sudah valid dan merupakan desain teruji dengan persentase total uji validitas yaitu $88,5 \%$ yang termasuk dalam kategori sangat baik.
\end{abstract}

Kata Kunci: LKPD, scientific approach, keterampilan Berpikir Kritis.

\begin{abstract}
This research was aimed to made the static fluid of student worksheet with the scientific approach to increase the critical thinking skill of the public high school student in Bengkulu. The research type was the Research and Development type that was the designed type was level 1 divided into five steps that is 1) a potency and problem, 2) literature study and information collecting, 3) a product design, 4) a design validation, 5) a design proved. The design validation was conducted by two judgments and two practitioners to test a product that developed both content appropriateness, the use of language, presentation, and graphics. Based on the result of the validation test, the content appropriateness aspect got 87,5\% (very well), the presentation aspect got $89,1 \%$ (very well), the graphic aspect got $93,8 \%$ (very well). Based on that result, it could be concluded that the static fluid of student worksheets with the scientific approach to increasing the critical thinking skill of the public high school student in Bengkulu that developed has valid and proved with the total percentage test got 88,5\% (very well).

Keyword: The static fluid of student worksheet, scientific approach, critical thinking skill.
\end{abstract}

\section{PENDAHULUAN}

Pendidikan merupakan suatu hal yang sangat penting bagi kehidupan seseorang untuk dapat menumbuhkan dan mengembangkan kemampuan atau potensi yang dimiliki oleh orang tersebut. Pendidikan dapat membuat seseorang merubah dari hal yang tidak tahu menjadi tahu, pendidikan juga membuat seseorang untuk dapat mencapai cita-cita yang diinginkan, meningkatkan mutu dan kecerdasan seseorang serta dapat mengembangkan potensi yang ada dalam diri seseorang sehingga dapat berguna dalam kehidupan bermasyarakat (Liani, Hamdani, \& Risdianto, 2018).

Permendikbud Nomor 20 Tahun 2016 tentang Standar Kompetensi Lulusan Pendidikan Dasar dan Menengah, menyatakan bahwa pada dimensi keterampilan siswa harus memiliki keterampilan berpikir dan bertindak kreatif, produktif, kritis, mandiri, kolaboratif, dan komunikatif melalui pendekatan ilmiah sebagai pengembangan dari yang dipelajari di satuan pendidikan dan sumber lain secara mandiri (Ningsih, Ramalis, \& Purwana, 2018).

Kemampuan berpikir kritis adalah suatu proses berpikir yang dapat diterima akal reflektif, rasional dan bertanggung jawab yang diarahkan untuk memutuskan apa yang dikerjakan atau diyakini, dalam hal ini tidak sembarangan untuk menganalisis suatu permasalahan dan menarik 
suatu kesimpulan (Sulardi, Nur, \& Widodo, 2015). Berpikir kritis adalah 1) Memberikan penjelasan sederhana (elementary clarification) yang melikupti (a) Memfokuskan pertanyaan, (b) Menganalisis argumen, (c) Bertanya dan menjawab pertanyaan tentang penjelasan/klarifikasi; 2) Membangun keterampilan dasar (Basic support) yang meliputi (a) Mempertimbangkan kredibilitas sumber (b) Mengobservasi dan mempertimbangkan laporan observasi; 3) Menyimpulkan (inference) yang meliputi (a) Mendeduksi dan mempertimbangkan hasil deduksi (b) Mendeduksi dan mempertimbangkan hasil induksi, (c) Membuat dan menentukan hasil pertimbangan; 4) Membuat penjelasan lanjut (advance clarification) yang meliputi (a) Mendefinisikan istilah dan mempertimbangkan suatu definisi, (b) Mengidentifikasi asumsi; 5) Mengatur strategi dan taktik (Strategy and tactics) yang meliputi (a) Menentukan suatu tindakan, (b) Berinteraksi dengan orang lain (Sakti, 2019).

Pembelajaran saintifik merupakan pembelajaran yang mengadopsi langkah-langkah saintis dalam membangun pengetahuan melalui metode ilmiah, maka model pembelajaran yang diperlukan adalah model yang memungkinkan dibudayakannya kecakapan berpikir sains(Haerullah, Hasan, \& Yusuf, 2019). Pendekatan saintifik (scientific approach) dalam pembelajaran sebagaimana dimaksud meliputi mengamati, menanya, mencoba, mengolah, dan mengkomunikasikan untuk semua mata pelajaran. Dalam mata pelajaran, materi, atau situasi tertentu, sangat mungkin pendekatan ilmiah ini tidak selalu tepat diaplikasikan secara prosedural. Pada kondisi seperti ini tentu saja proses pembelajaran harus tetap menerapkan nilai-nilai atau sifatsifat ilmiah serta menghindari nilai-nilai atau sifat-sifat non ilmiah (Setiawan, 2017).

Langkah pembelajaran dengan pendekatan Scientific dalam penelitian dapat dilihat dalam tabel berikut ini (Umbaryati, 2013)

Tabel 1 Langkah Pembelajaran Scientific approach

\begin{tabular}{|c|c|}
\hline $\begin{array}{c}\text { Langkah } \\
\text { Pembelajaran }\end{array}$ & Kegiatan belajar \\
\hline Mengamati & $\begin{array}{l}\text { Siswa membaca, mendengar, menyimak, melihat (tanpa atau } \\
\text { dengan alat). }\end{array}$ \\
\hline Menanya & $\begin{array}{l}\text { Siswa mengajukan pertanyaan tentang informasi yang tidak } \\
\text { dipahami dari apa yang diamati atau pertanyaan untuk } \\
\text { mendapatkan informasi tambahan tentang apa yang diamati. }\end{array}$ \\
\hline $\begin{array}{l}\text { Mengumpulkan } \\
\text { informasi }\end{array}$ & $\begin{array}{l}\text { Siswa melakukan eksperimen ,membaca sumber lain selain } \\
\text { buku teks, mengamati objek atau kejadian, aktivitas wawancara } \\
\text { dengan narasumber. }\end{array}$ \\
\hline $\begin{array}{l}\text { Mengasosiasi/ } \\
\text { Menalar }\end{array}$ & $\begin{array}{l}\text { Siswa mengolah informasi yang sudah dikumpulkan baik } \\
\text { terbatas dari hasil kegiatan mengumpulkan/eksperimen maupun } \\
\text { hasil dari kegiatan mengamati dan kegiatan mengumpulkan } \\
\text { informasi. }\end{array}$ \\
\hline $\begin{array}{l}\text { Mengkomunika } \\
\text { sikan }\end{array}$ & $\begin{array}{l}\text { Siswa menyampaikan hasil pengamatan dan menyampaikan } \\
\text { kesimpulan }\end{array}$ \\
\hline
\end{tabular}

Bahan ajar adalah segala macam bahan yang disiapkan dan digunakan guru untuk membantu melaksanakan kegiatan belajar mengajar di kelas. Dengan demikian bahan ajar akan membantu siswa menjadi aktif dan memahami materi yang diajarkan serta dapat mengembangkan kemampuan berpikirnya sendiri (Rangsing \& Handayani, 2015). Jenis bahan ajar dikelompokkan menjadi empat, yaitu: 1) bahan cetak antara lain handout, buku, modul, lembar kerja siswa, brosur, leaflet, wallchart, foto/gambar, model/maket; 2) bahan ajar dengar (audio) seperti kaset, radio, piringan hitam, dan CD audio; 3) bahan ajar pandang dengar (audio visual) seperti video CD, film; dan 4) bahan ajar interaktif seperti CD interaktif'. Empat jenis bahan ajar tersebut akan sangat bermanfaat dalam proses pembelajaran jika digunakan secara tepat sesuai dengan tujuan pembelajaran yang akan dicapai (Arsanti, 2018).

Lembar Kerja Peserta Didik (LKPD) merupakan lembaran berisi tugas-tugas yang harus dikerjakan oleh peserta didik (LESTARI, 2018). LKPD yang digunakan merupakan LKPD dari 
penerbit dan tidak dibuat oleh guru sendiri padahal LKPD dapat dibuat sendiri oleh guru yang bersangkutan sehingga LKPD dapat lebih menarik serta lebih kontekstual dengan situasi dan kondisi sekolah ataupun lingkungan sosial budaya peserta didik (Fitriah \& Ismono, 2017). LKS bukanlah perangkat yang baru bagi guru dalam proses penyampaian pembelajaran. LKS yang beredar luas di sekolah hanya berisi ringkasan dari materi pelajaran atau review dari pokok bahasan setiap topik yang akan dipelajari siswa, serta berisi latihan soal yang terdiri dari pertanyaanpertanyaan, baik LKS yang disusun sendiri oleh guru tersebut maupun LKS yang dirancang oleh penerbit (Mayasari, Syamsurizal, \& Maison, 2015). Ada beberapa fungsi umum LKPD yaitu: 1) sebagai bahan ajar yang bisa meminimalkan peran pendidik, namun lebih mengaktifkan peserta didik; 2) sebagai bahan ajar yang memudahkan peserta didik untuk memahami materi yang diberikan; 3) sebagai bahan ajar yang ringkas dan kaya tugas untuk berlatih serta memudahkan pelaksanaan pengajaran kepada peserta didik; 4) alternatif bagi guru untuk mengarahkan pengajaran atau memperkenalkan suatu kegiatan tertentu sebagai kegiatan belajar mengajar; 5) dapat digunakan untuk mempercepat proses pengajaran dan menghemat waktu penyajian suatu topic (Mahmudah, 2017).

Berdasarkan hasil wawancara yang dilakukan dengan guru mata pelajaran fisika kelas XI SMA Negeri 1 Kota Bengkulu diperoleh beberapa fakta yaitu, (a) metode pembelajaran yang sering digunakan adalah metode ceramah, tutor sebaya, dan latihan soal. (b) Penerapan metode eksperimen dilakukan dengan menggunakan LKPD (Lembar Kerja Peserta Didik) buatan Guru. LKPD ini belum secara khusus dikembangkan untuk meningkatkan keterampilan berpikir kritis siswa (c) Nilai rata-rata hasil belajar harian relatif rendah. (d) Siswa-siswi masih kurang aktif dalam proses pembelajaran berlangsung. (e) Dalam aspek keterampilan berpikir kritis siswa juga masih rendah pada beberapa aspek seperti pada aspek keterampilan membuat hipotesis, merencanakan percobaan, menggunakan alat dan bahan, mengamati dan menafsirkan.

Penelitian yang relevan dengan penelitian ini yaitu penelitian Khasanah dan Imam 2019. penelitian Khasanah dan Imam 2019 memiliki beberapa kelemahan yaitu tidak adanya ringkasan materi, mengkomunikasikan (mempresentasikan hasil percobaan didepan kelas), tugas pendahuluan dan latihan soal menggunakan taksonomi Bloom C4, C5, dan C6 yang dapat melatih keterampilan berpikir kritis siswa (Khasanah \& Supardi, 2019).

Berdasarkan uraian tersebut di atas, maka perlu dilakukan penelitian yang bertujuan untuk: 1) Menghasilkan Lembar Kerja Peserta Didik (LKPD) Fluida Statis dengan Scientific Approach untuk meningkatkan Keterampilan Berpikir Kritis Siswa SMAN Kota Bengkulu, dan 2) Mengetahui kelayakan Lembar Kerja Peserta Didik (LKPD) Fluida Statis dengan Scientific Approach untuk meningkatkan Keterampilan Berpikir Kritis Siswa SMAN Kota Bengkulu.

\section{METODE PENELITIAN}

Metode yang digunakan dalam penelitian ini adalah metode Research and Development (R\&D). Metode R\&D (Research and Development) adalah metode penelitian yang digunakan untuk menghasilkan produk tertentu dan menguji keefektifan produk tersebut (Sugiyono, 2018).

Metode yang digunakan adalah R\&D tipe rancangan level 1. Langkah-langkah R\&D tipe rancangan level 1 dapat di; ihat pada gambar 1.

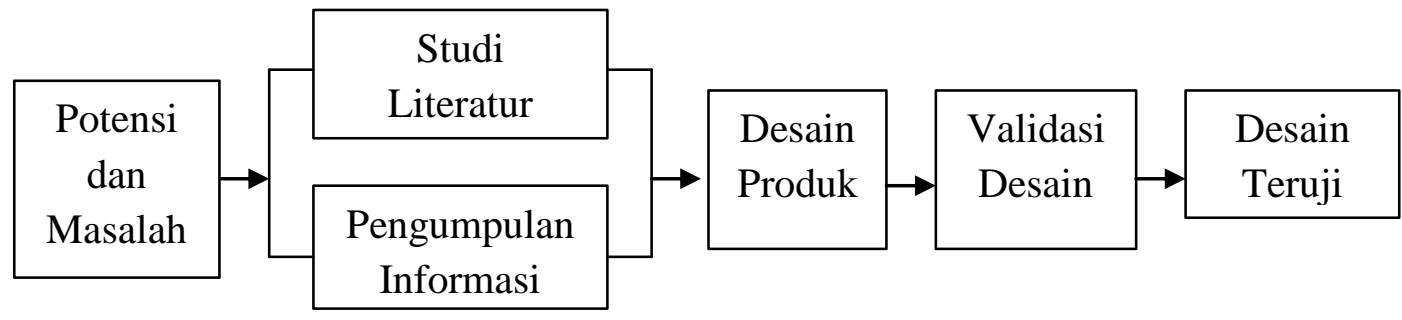

Gambar 1 Langkah-langkah Penelitian R\&D Level 1

Langkah-langkah penelitian research and development tipe rancangan level 1 ada lima, yaitu 1) potensi dan masalah, 2) studi literatur dan pengumpulan data, 3) desain produk, 4) validasi desain, 5) desain teruji (Sugiyono, 2018). Penelitian yang dilakukan hanya menghasilkan 
rancangan produk dan rancangan tersebut divalidasi secara internal (pendapat ahli dan praktisi) kemudian diuji coba dengan skala terbatas pada siswa. Penelitian ini menghasilkan LKPD fluida statis dengan scientific approach untuk meningkatkan keterampilan berpikir kritis siswa.

Angket untuk validator dalam bentuk skala Likert menggunakan empat pilihan jawaban seperti yang tertera pada tabel 2 di bawah ini.

\begin{tabular}{cc}
\multicolumn{2}{c}{ Tabel 2 Kriteria Penilaian Angket Validator } \\
\hline Nilai & Pernyataan \\
\hline 1 & Tidak Baik \\
2 & Cukup \\
3 & Baik \\
4 & Sangat Baik \\
\hline
\end{tabular}

Validator tidak akan menjawab salah satu jawaban kualitatif yang telah disediakan, tetapi menjawab salah satu jawaban kuantitatif yang telah disediakan.

Analisis hasil uji validasi dilakukan secara deskriptif menggunakan rumus berikut.

$$
p=\frac{n}{N} \times 100 \%
$$

dengan $\mathrm{P}$ adalah persentase hasil uji validasi, $\mathrm{n}$ adalah skor total penilaian ahli, dan $\mathrm{N}$ adalah skor maksimal yang mungkin diperoleh (RIZAL, 2018).

Kriteria penilaian skor rata-rata dan presentase menurut dapat dilihat pada tabel 3.

Tabel 3 Kriteria Interpretasi Skor

\begin{tabular}{cc}
\hline Persentase (\%) & Kriteria \\
\hline$\leq 25$ & Sangat kurang \\
$26-50$ & Kurang \\
$51-75$ & Baik \\
$76-100$ & Sangat Baik
\end{tabular}

LKPD yang dikembangkan dapat dikatakan baik/layak apabila memenuhi kriteria kelayakan isi dengan persentase $\geq 51 \%$

\section{HASIL DAN PEMBAHASAN}

\subsection{Deskripsi Data Hasil Penelitian}

Langkah-langkah penelitian untuk menghasilkan produk berupa LKPD fisika dengan scientific approach untuk meningkatkan keterampilan berpikir kritis siswa, sebagai berikut :

\subsubsection{Deskripsi Data Potensi dan Masalah}

Pada tahap potensi dan masalah dilakukan dengan lembar observasi yang dilakukan di SMAN 1 Kota Bengkulu. Potensi yang ditemukan yaitu kurikulum yang digunakan yaitu kurikulum 2013, dalam proses pembelajaran fisika siswa tidak terlalu antusias dalam mengikuti proses pembelajaran, guru masih menggunakan metode konvensional dalam mengajar sehingga guru yang terlibat aktif sedangkan siswa hanya mendengar penjelasan guru dalam proses pembelajaran fisika di kelas, bahan ajar yang digunakan guru dan siswa berupa buku cetak yang disediakan oleh sekolah.

\subsubsection{Deskripsi Data Studi Literatur dan pengumpulan informasi}

Penelitian yang dilakukan oleh Husna, Syamsurizal, \& Maison (2015) dengan judul pengembangan Lembar Kerja Siswa (LKS) Berbasis Karakter Melalui Pendekatan Saintifik Pada Materi Fluida Statik Untuk Sekolah Menengah Atas. Berdasarkan hasil pengamatan di SMA Negeri Titian Teras H.Abdurrahman Sayoeti, kendala utama yang dialami guru fisika dalam menerapkan 
kurikulum 2013 adalah bagaimana merancang / merencanakan pelaksanaan pembelajaran yang sesuai dengan kriteria yang diharapkan yaitu pembelajaran dengan pendekatan saintifik.

Penelitian yang dilakukan oleh Khasanah dan Imam (2019) dengan judul pengembangan LKPD Berbasis Pendekatan Saintifik Untuk Melatihkan Keterampilan Berpikir Kritis didapatkan hasil bahwa berdasarkan Prapenelitian yang dilakukan di SMA Negeri 1 Porong melalui angket yang diberikan pada peserta didik, sebagian besar peserta didik menyatakan Fisika merupakan pelajaran yang menarik untuk dipelajariNamun, peserta didik juga menyatakan Fisika merupakan mata pelajaran yang sulit dipahami karena Fisika memiliki banyak rumus. Sehingga peserta didik hanya terpacu pada rumus Fisika bukan pada konsep materi Fisika. hal tersebut menyebabkan keterampilan berpikir kritis pada peserta didik kurang terlatihkan secara maksimal.

\subsubsection{Deskripsi Data Desain Produk}

Desain LKPD fluida statis dengan scientific approach untuk meningkatkan keterampilan berpikir kritis siswa terdiri dari: 1) Halaman Sampul (berisi Judul dan Identitas Siswa) 2)Kata Pengantar 3)Daftar Isi 4)Pendahuluan yang terdiri dari:Petunjuk Belajar, Kompetensi Dasar, Indikator, Tujuan Pembelajaran, Ringkasan Mater, Sintak scientific approach yang terdiri dari mengamati, menanya, mengumpulkan informasi, menalar dan mengkomunikasikan serta Indikator Keterampilan Berpikir Kritis yang terdiri dari memberikan penjelasan sederhana, membangun keterampilan dasar, menyimpulkan, membuat penjelasan lanjut, mengatur strategi dan taktik 5) Tugas pendahuluan 6) Latihan soal 7) Daftar Pustaka dan 8) Kunci jawaban.

\subsubsection{Deskripsi Data Validasi Desain}

Data uji validitas teridiri dari aspek Kelayakan isi, Penggunaan Bahasa, Penyajian,dan Kegrafisan.

Tabel 4 Hasil Uji Validitas Aspek Kelayakan Isi Oleh Ahli dan Praktisi

\begin{tabular}{ccccc}
\hline Validator & $\begin{array}{c}\text { Skor } \\
\text { Total (n) }\end{array}$ & $\begin{array}{c}\text { Skor } \\
\text { Maksimal (N) }\end{array}$ & $\begin{array}{c}\text { Persentase } \\
P=\frac{n}{N} \times 100 \%\end{array}$ & Kategori \\
\hline Ahli I & 54 & 60 & $90 \%$ & Sangat baik \\
Ahli II & 50 & 60 & $83,3 \%$ & Sangat baik \\
Praktisi I & 52 & 60 & $86,8 \%$ & Sangat baik \\
Praktisi II & 54 & 60 & $90 \%$ & Sangat baik \\
Total & 210 & 240 & $87,5 \%$ & Sangat baik \\
\hline
\end{tabular}

Berdasarkan tabel 4, aspek kelayakan isi yang dilakukan 2 ahli dan 2 praktisi diperokeh persentase rata-rata sebesar $87,5 \%$ dengan kategori sangat baik.

Tabel 5 Hasil Uji Validitas Aspek Penggunaan Bahasa Oleh Ahli dan Praktisi

\begin{tabular}{ccccc}
\hline Validator & $\begin{array}{c}\text { Skor } \\
\text { Total (n) }\end{array}$ & $\begin{array}{c}\text { Skor Maksimal } \\
(\mathbf{N})\end{array}$ & $\begin{array}{c}\text { Persentase } \\
P=\frac{n}{N} \times 100 \%\end{array}$ & Kategori \\
\hline Ahli I & 32 & 36 & $88,9 \%$ & Sangat baik \\
Ahli II & 31 & 36 & $86,1 \%$ & Sangat baik \\
Praktisi I & 27 & 36 & $75 \%$ & Sangat Baik \\
Praktisi II & 30 & 36 & $83,3 \%$ & Sangat Baik \\
Total & 120 & 144 & $83,3 \%$ & Sangat Baik \\
\hline
\end{tabular}

Berdasarkan tabel 5, aspek penggunaan bahasa yang dilakukan 2 ahli dan 2 praktisi diperokeh persentase rata-rata sebesar $83,3 \%$ dengan kategori sangat baik. 
Tabel 6 Hasil Uji Validitas Aspek Penyajian Oleh Ahli dan Praktisi

\begin{tabular}{ccccc}
\hline Validator & $\begin{array}{c}\text { Skor } \\
\text { Total (n) }\end{array}$ & $\begin{array}{c}\text { Skor } \\
\text { Maksimal (N) }\end{array}$ & $\begin{array}{c}\text { Persentase } \\
P=\frac{n}{N} \times 100 \%\end{array}$ & Kategori \\
\hline Ahli I & 14 & 16 & $87,5 \%$ & Sangat baik \\
Ahli II & 14 & 16 & $87,5 \%$ & Sangat baik \\
Praktisi I & 15 & 16 & $93,7 \%$ & Sangat baik \\
Praktisi II & 14 & 16 & $87,5 \%$ & Sangat baik \\
Total & 57 & 64 & $89,1 \%$ & Sangat baik \\
\hline
\end{tabular}

Berdasarkan tabel 6, aspek penyajian yang dilakukan 2 ahli dan 2 praktisi diperokeh persentase rata-rata sebesar $89,1 \%$ dengan kategori sangat baik.

Tabel 7 Hasil Uji Validitas Aspek Kegrafisan Oleh Ahli dan Praktisi

\begin{tabular}{ccccc}
\hline Validator & $\begin{array}{c}\text { Skor } \\
\text { Total (n) }\end{array}$ & $\begin{array}{c}\text { Skor } \\
\text { Maksimal (N) }\end{array}$ & $\begin{array}{c}\text { Persentase } \\
P=\frac{n}{N} \times 100 \%\end{array}$ & Kategori \\
\hline Ahli I & 12 & 12 & $100 \%$ & Sangat baik \\
Ahli II & 12 & 12 & $100 \%$ & Sangat baik \\
Praktisi I & 10 & 12 & $83,3 \%$ & Sangat baik \\
Praktisi II & 11 & 12 & $91,5 \%$ & Sangat baik \\
Total & 45 & 48 & $93,8 \%$ & Sangat baik \\
\hline
\end{tabular}

Berdasarkan tabel 7, aspek kegrafisan yang dilakukan 2 ahli dan 2 praktisi diperokeh persentase rata-rata sebesar 93,8\% dengan kategori sangat baik.

\subsubsection{Deskripsi Data Desain Teruji}

Pada tahap ini dilakukan revisi berdasarkan saran dari validator. Revisi dilakukan pada aspek penyajian. Revisi dilakukan pada bagian materi massa jenis, berat jenis dan tekanan hidrostatis karena rumus yang diberikan secara langsung bukan dari penurunan rumus. Untuk aspek kelayakan isi, penggunaan bahasa, dan kegrafisan tidak dilakukan revisi karena berdasarkan hasil uji validitas aspek kelayakan isi, penggunaan bahasa, dan kegrafisan berada dalam kategori sangat baik.

\subsection{Pembahasan}

Tujuan penelitian ini adalah untuk menghasilkan dan mengetahui kelayakan LKPD fluida statis dengan scientific approach untuk meningkatkan keterampilan berpikir kritis siswa yang valid. Pengembangan produk ini menggunakan langkah-langkah penelitian $R \& D$ dengan tipe rancangan level 1 yaitu potensi dan masalah, studi literatur dan pengumpulan informasi, desain produk, validasi desain, dan desain teruji.

Berdasarkan hasil observasi yang di SMAN 1 Kota Bengkulu ditemukan masalah yaitu siswa kurang antusias atau tertarik dalam mengikuti pembelajaran fisika dikarenakan proses pembelajaran yang membosankan dan hanya mendengar penjelasan materi dari guru, guru menggunakan metode konvensional sehingga siswa kurang berperan aktif di dalam kelas, siswa dan guru hanya menggunakan buku cetak yang ada di sekolah dan belum menggunakan bahan ajar tambahan.

Studi literatur dilakukan untuk mengumpulkan pendukung untuk pengembangan produk yaitu dengan mengumpulkan informasi melalui jurnal yang relevan denga penelitian. Penelitian yang dilakukan oleh Khasanah dan Imam (2019) dengan judul pengembangan LKPD berbasis pendekatan saintifik untuk melatihkan keterampilan berpikir kritis, masih adanya kelemahan yaitu 
tidak ada ringkasan materi, mempresentasikan hasil percobaan didepan kelas, latihan soal, dan kunci jawaban

Desain awal yang didapat dari hasil penelitian Khasanah dan Imam memiliki beberapa kelemahan yaitu tidak adanya ringkasan materi, mengkomunikasikan (mempresentasikan hasil percobaan didepan kelas), tugas pendahuluan dan latihan soal menggunakan taksonomi Bloom C4, C5, dan C6 yang dapat melatih keterampilan berpikir kritis siswa. Hasil LKPD fluida statis dengan scientific approach untuk meningkatkan keterampilan berpikir kritis siswa sebagai berikut yaitu cover, pendahuluan, ringkasan materi, lembar pratikum massa jenis, lembar pratikum hukum pascal, lembar pratikum hukum acrchimedes, tugas pendahuluan, latihan soal dan kunci jawaban.

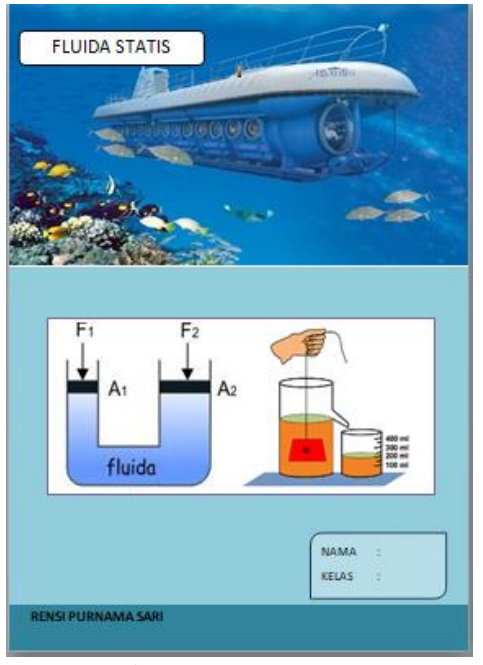

Gambar 2 Cover LKPD

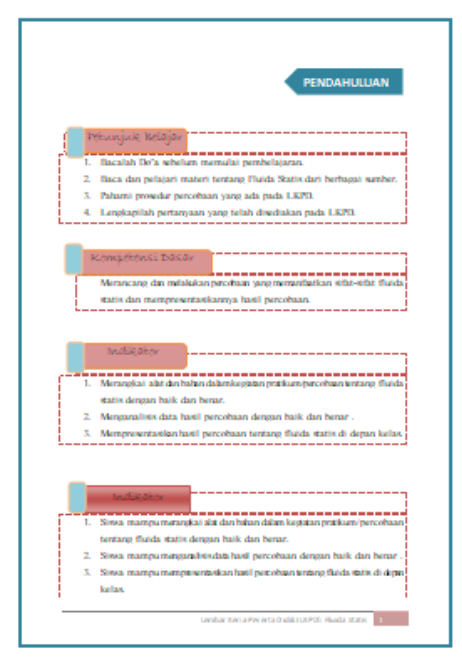

Gambar 3 Bagian Pendahuluan

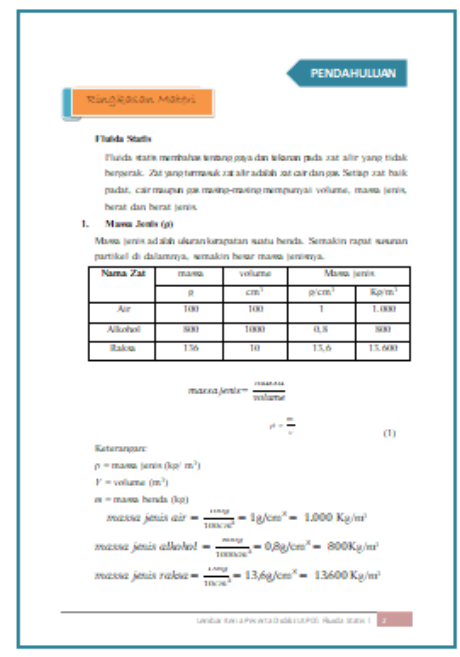

Gambar 4 Ringkasan Materi

Pada bagian awal LKPD terdapat cover yang berisi judul LKPD beserta gambar-gambar pendukungnya. Setelah cover ada bagian pendahuluan yang terdiri dari petunjuk kerja, kompetensi dasar, indicator dan ringkasan materi

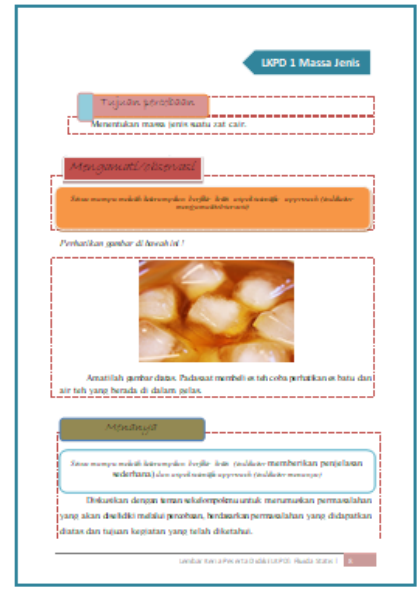

Gambar 5 Lembar Praktikum Massa Jenis

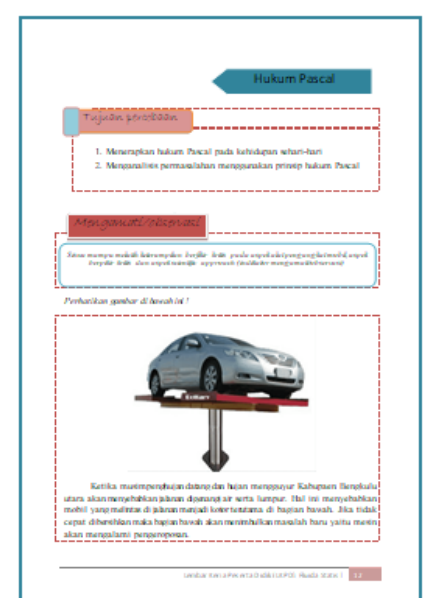

Gambar 6 Lembar Praktikum Hukum Pascal

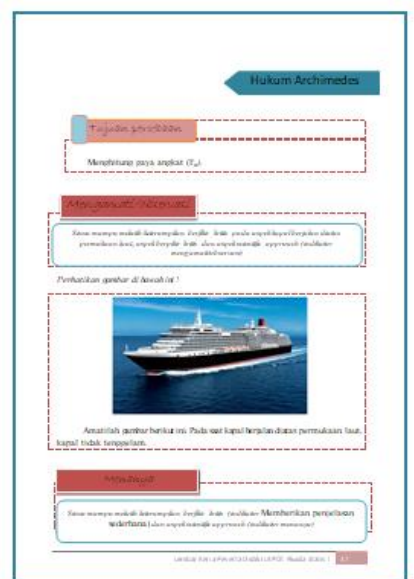

Gambar 7 Lembar Praktikum Hukum Archimedes

Di dalam LKPD ini terdapat 3 lembar praktikum yang terdiri dari lembar praktikum massa jenis, lembar praktikum Hukum Pascal, dan lembar praktikum Hukum Archimedes. 


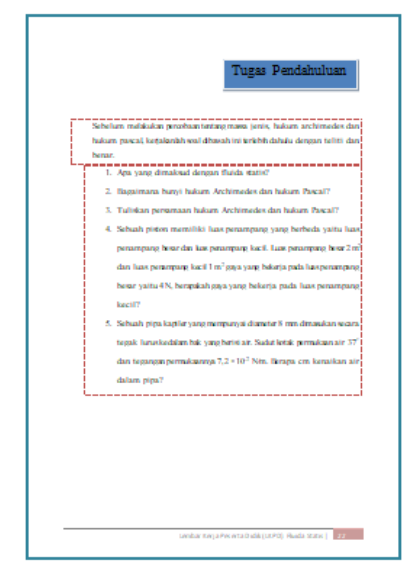

Gambar 8 Tugas Pendahuluan

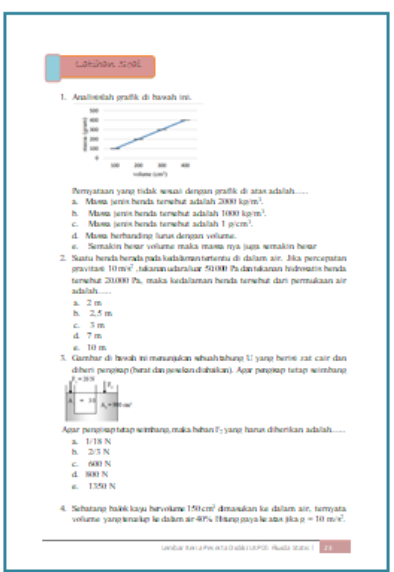

Gambar 9 Latihan Soal

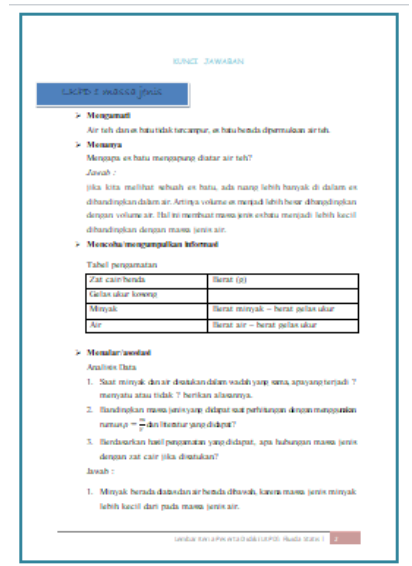

Gambar 10 Kunci Jawaban

Selain lembar praktikum, LKPD ini juga dilengkapi dengan lembar tugas pendahuluan, latihan soal dan kunci jawaban.

Berdasarkan hasil uji validitas ya ng dilakukan oleh 2 ahli dan 2 praktisi diperoleh persentase rata-rata validitas pada aspek kelayakan isi yaitu 87,5\% denga kategori sangat baik, pada aspek penggunaan bahasa diperoleh persentase rata-rata 83,3\% dengan kategori sangat baik, pada aspek penyajian diperoleh persentase rata-rata $89,1 \%$ dengan kategori sangat baik dan pada aspek kegrafisan diperoleh persentase rata-rata 93,8\% dengan kategori sangat baik. Sehingga didapatkan persentase rata-rata dari keempat aspek yaitu $88,5 \%$ denga kategori sangat baik.

Pada tahap ini dilakukan revisi berdasarkan saran dari validator. Revisi dilakukan pada aspek penyajian. Revisi dilakukan pada bagian materi massa jenis, berat jenis dan tekanan hidrostatis karena rumus yang diberikan secara langsung bukan dari penurunan rumus. Untuk aspek kelayakan isi, penggunaan bahasa, dan kegrafisan tidak dilakukan revisi karena berdasarkan hasil uji validitas aspek kelayakan isi, penggunaan bahasa, dan kegrafisan berada dalam kategori sangat baik.

\section{SIMPULAN DAN SARAN}

\subsection{Simpulan}

Berdasarkan uji internal oleh judgement ahli dan praktisi, LKPD yang dikembangkan termasuk dalam kategori layak dan merupakan desain teruji karena mendapatkan respon positif dengan presentase validitas yaitu $88,5 \%$ dengan kategori sangat baik.

\subsection{Saran}

LKPD yang dibuat memiliki keterbatasan dalam penelitian yaitu belum diuji coba secara terbatas. Untuk pengembangan lanjutan, produk akhir dari penelitian ini dapat diuji secara eksternal dengan menggunakan metode penelitian research and development tipe rancangan level 2.

\section{UCAPAN TERIMA KASIH}

Penulis mengucapkan terimakasih kepada validator ahli dan praktisi yang sudah bersedia untuk membatu pengisian angket validasi pengembangan LKPD fluida statis dengan scientific approach untuk meningkatkan keterampilan berpikir kritis siswa SMAN Kota Bengkulu.

\section{DAFTAR PUSTAKA}

Arsanti, M. (2018). PENGEMBANGAN BAHAN AJAR MATA KULIAH PENULISAN KREATIF BERMUATAN NILAI-NILAI PENDIDIKAN KARAKTER RELIGIUS BAGI MAHASISWA PRODI PBSI, FKIP, UNISSULA Meilan Arsanti Email : meilanarsanti@unissula.ac.id Prodi Pendidikan Bahasa dan Sastra Indonesia , Fakulta. Jurnal 
Kredo, 1(2), 71-90.

Fitriah, U. N., \& Ismono. (2017). LKPD BERORIENTASI PENDEKATAN CONTEXTUAL TEACHING AND LEARNING UNTUK MELATIHKAN KETERAMPILAN BERPIKIR KRITIS PADA MATERI KELARUTAN DAN HASIL KALI KELARUTAN. Unesa Journal of Chemical Education, 6(2), 238-242.

Haerullah, A., Hasan, S., \& Yusuf, M. (2019). PERANGKAT PEMBELAJARAN IPA BERPOLA PBMP DIPADU SCIENTIFIC APPROACHTERINTEGRASI NILAI ISLAMI UNTUK BERPIKIR KRITIS DAN METAKOGNISI SISWA SEKOLAH/MADRASAH MULTIETNIS. EDUKASI - Jurnal Pendidikan, 17(2), 85-100.

Khasanah, S. M., \& Supardi, I. (2019). PENGEMBANGAN LKPD BERBASIS PENDEKATAN SAINTIFIK UNTUK MELATIHKAN KETERAMPILAN BERPIKIR KRITIS. IPF : Inovasi Pendidikan Fisika, 08(03), 799-803.

LESTARI, E. A. (2018). PENGEMBANGAN LEMBAR KERJA PESERTA DIDIK (LKPD) BERBASIS EKSPERIMEN IPA KELAS V SD/MI. UNIVERSITAS ISLAM NEGERI RADEN INTAN.

Liani, E., Hamdani, D., \& Risdianto, E. (2018). Penerapan Model Problem Based Learning dengan Metode Brainstorming untuk Meningkatkan Kemampuan Pemecahan Masalah Siswa di SMAN 3 Kota Bengkulu. Jurnal Kumparan Fisika, 1, 20-24.

Mahmudah, S. (2017). Pengembangan Lembar Kerja. Universitas Lampung.

Mayasari, H., Syamsurizal, \& Maison. (2015). Pengembangan Lembar Kerja Siswa (LKS) Berbasis Karakter melalui Pendekatan Saintifik pada Materi Fluida Statik untuk Sekolah Menengah Atas. Edu-Sains, 3(2), 30-36.

Ningsih, D. R., Ramalis, T. R., \& Purwana, U. (2018). PENGEMBANGAN TES KETERAMPILAN BERPIKIR KRITIS BERDASARKAN ANALISIS TEORI RESPON BUTIR. Jurnal Wahana Pendidikan Fisika, 3(2), 45-50.

Rangsing, B., \& Handayani, D. (2015). PENGEMBANGAN BAHAN AJAR FISIKA BERBASIS MAJALAH SISWA PINTAR FISIKA ( MSPF ) PADA PEMBELAJARAN IPA DI SMP ( Pokok Bahasan Gerak Pada Benda ). Jurnal Pembelajaran Fisika, 4(3), $243-247$.

RIZAL, M. (2018). PENGEMBANGAN LKPD MATEMATIKA BERBASIS PROBLEM BASED LEARNING UNTUK MENINGKATKAN KEMAMPUAN HIGHER ORDER THINKING SKILLS PESERTA DIDIK KELAS IV SD. UNIVERSITAS LAMPUNG.

Sakti, I. (2019). IMPLEMENTASI MODEL PERANGKAT PEMBELAJARAN BERORIENTASI HOTS ( HIGH ORDER THINKING SKILLS ) DAN PENDIDIKAN KARAKTER MELALUI PBL ( PROBLEM BASED LEARNING ) PADA MATA KULIAH FISIKA DASAR. Prosiding Seminar Nasional Fisika (E-Journal), 8(3), 389-400.

Setiawan, D. (2017). PENDEKATAN SAINTIFIK DAN PENILAIAN AUTENTIK UNTUK MENINGKATKAN MUTU PEMBELAJARAN PENDIDIKAN AGAMA ISLAM. Journal Of Basic Education, 01(02), 34-46.

Sugiyono. (2018). Metode Penelitian \& Pengembangan ( Research and Development/ $R \& D$ ). Bandung: ALFABETA.

Sulardi, Nur, M., \& Widodo, W. (2015). PENGEMBANGAN PERANGKAT PEMBELAJARAN FISIKA MODEL PROBLEM BASED LEARNING ( PBL ) UNTUK MELATIH KETERAMPILAN BERPIKIR. Pendidikan Sains Pascasarjana Universitas Negeri Surabaya, 5(1), 802-810.

Umbaryati. (2013). Pentingnya LKPD pada Pendekatan Scientific Pembelajaran Matematika. 217225. 